\title{
Functional mitral stenosis: a result of bacterial endocarditis
}

\author{
Alexander Marcus Dashwood, Naim Masnun Mridha, Myo T Lwin
}

Department of Cardiology, Gold Coast University Hospital, Southport, Queensland, Australia

\section{Correspondence to} Dr Alexander Marcus Dashwood, icuris247@googlemail.com

Accepted 22 January 2017

CrossMark

To cite: Dashwood AM, Mridha NM, Lwin MT. BMJ Case Rep Published online: [please include Day Month Year] doi:10.1136/bcr-2017219216

\section{DESCRIPTION}

A 72-year-old man received a non-emergent drugeluting stent to mid-right coronary artery (RCA) for chest pain. He represented 3 weeks later with congestive cardiac failure and rigours. Blood cultures grew Streptococcus sanguinis (viridans); there was no history of rheumatic disease; however, a root canal abscess was treated 3 months prior. Transthoracic echocardiograms (TTE) revealed a thickened anterior mitral valve (MV) and posterior directed jet of mitral regurgitation as well as thickened, restricted posterior mitral valve leaflet (PMVL) with an insignificant gradient of $3 \mathrm{~mm} \mathrm{Hg}$. Transoesophageal echocardiogram (TOE) revealed a large $3.0 \times 1.5 \mathrm{~cm}$ anterior MV vegetation causing functional mitral stenosis (MS) with a mean gradient of $10 \mathrm{~mm} \mathrm{Hg}$ (figure 1). He went on to receive a mechanical MV replacement 5 days after diagnosis.
Infective endocarditis (IE) typically results in valvular insufficiency and rarely causes obstructive or functional stenosis like in this case. A considerable portion occur in patients with preexisting MS. ${ }^{1}$ Inflammation from IE may be confined to the surface of the valve, perpetuating endothelial damage while preserving underlying tissue architecture. Bacterial growth and deposition of fibrin and platelets across the expanding inflamed endocardium surface propagates further vegetation until the accumulative expansion becomes obstructive, leading to valvular stenosis.

Given the rarity of bacterial endocarditis causing valvular stenosis, fungal endocarditis is usually suspected; however, Staphylococci organisms appear to be the most common bacteria. ${ }^{2}$ Treatment is medically challenging and invariably requires surgery. Early recognition and management is

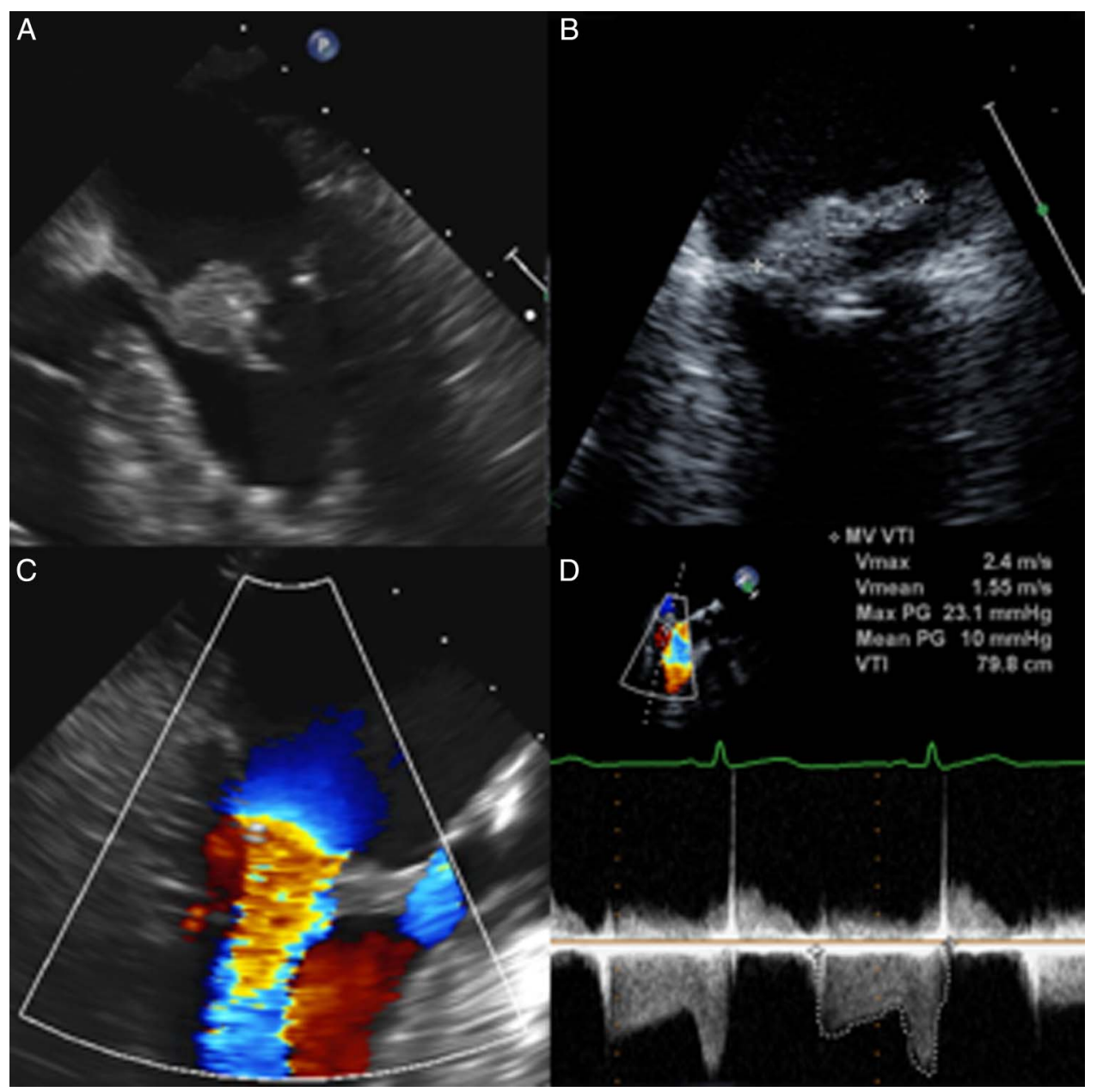

Figure 1 Transoesophageal echocardiogram findings: (A) mid-oesophageal four chamber view showing $3.0 \times 1.5 \mathrm{~cm}$ anterior mitral valve vegetation, (B) mid-oesophageal at $54^{\circ}$ showing larger anterior mitral valve leaflet vegetation, (C) mid-oesophageal long axis showing posterior directed jet of mitral regurgitation, and (D) continuous wave Doppler with a mean gradient of $10 \mathrm{~mm} \mathrm{Hg}$. 
crucial, with TOE being the accepted diagnostic investigation. Heart failure is the most common cause of death.

\section{Learning points}

- Bacterial infective endocarditis typically results in valvular insufficiency and rarely causes a functional obstruction.

- Inflammation of valve surface perpetuates endothelial damage while preserving underlying tissue architecture. Fibrin, platelets and bacterial growth aggregate to eventually cause obstruction.

- Early diagnosis (transoesophageal echocardiogram) and management (usually surgery) are crucial for patient outcomes.

- Heart failure is the commonest cause of death.
Contributors AMD recognised and conceived the case. NMM and MTL contributed to the researching, editing, refinement and submission of the paper. All authors reviewed and approved the final manuscript.

Competing interests None declared.

Patient consent Obtained.

Provenance and peer review Not commissioned; externally peer reviewed.

\section{REFERENCES}

1 Melgar GR, Nasser RM, Gordon SM, et al. Fungal prosthetic valve endocarditis in 16 patients. an 11-year experience in a tertiary care hospital. Medicine (Baltimore) 1997;76:94-103.

2 Tiong IY, Novaro GM, Jefferson B, et al. Bacterial endocarditis and functional mitral stenosis: a report of two cases and brief literature review. Chest 2002;122:2259-62.

Copyright 2017 BMJ Publishing Group. All rights reserved. For permission to reuse any of this content visit http://group.bmj.com/group/rights-licensing/permissions.

BMJ Case Report Fellows may re-use this article for personal use and teaching without any further permission.

Become a Fellow of BMJ Case Reports today and you can:

- Submit as many cases as you like

- Enjoy fast sympathetic peer review and rapid publication of accepted articles

- Access all the published articles

- Re-use any of the published material for personal use and teaching without further permission

For information on Institutional Fellowships contact consortiasales@bmjgroup.com

Visit casereports.bmj.com for more articles like this and to become a Fellow 